\title{
Ulcerative colitis, autoimmune hemolytic anemia and primary sclerosing cholangitis in a child
}

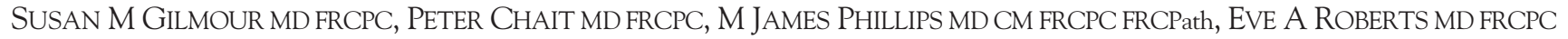

SM GILMOUR, P CHAIT, MJ PHILliPs, EA RoberTs. Ulcerative colitis, autoimmune hemolytic anemia and primary sclerosing cholangitis in a child. Can J Gastroenterol 1996;10(5):301-303. A 15-month-old female who initially presented with autoimmune hemolytic anemia (AIHA) is described. She developed bloody stools and was diagnosed with ulcerative colitis (UC). Investigations of persistent hepatomegaly revealed primary sclerosing cholangitis (PSC). The association of AIHA, UC and PSC has never been reported. All these conditions entail impaired immunoregulation. Patients with a clustering of autoimmune diseases may help to delineate the pathogenesis of UC. Autoimmune phenomena may be prominent in inflammatory bowel disease. UC, in particular, exhibits a high incidence of associated autoimmune diseases including hypothyroidism, PSC, vitiligo and alopecia areata. AIHA is well described in $0.5 \%$ to $1.0 \%$ of adult UC patients but has not been reported in children with UC.

Key Words: Autoimmune hemolytic anemia, Autoimmune phenomena, Child, Primary sclerosing cholangitis, Ulcerative colitis
Colite ulcéreuse, anémie hémolytique autoimmune et cholangite sclérosante primitive chez un enfant

RÉSUMÉ : On décrit ici le cas d'une fillette de 15 mois chez qui on avait d'abord diagnostiqué une anémie hémolytique auto-immune. Elle a présenté des selles sanguinolentes et a reçu un diagnostic de colite ulcéreuse. L'observation d'une hépatomégalie persistante a révélé la présence d'une cholangite sclérosante primitive. L'association anémie hémolytique autoimmune, colite ulcéreuse et cholangite sclérosante primitive n'avait encore jamais été signalée. Ces trois maladies sont liées à une anomalie de l'immunorégulation. Les patients qui présentent des maladies autoimmunes concomitantes peuvent contribuer à délimiter la pathogenèse de la colite ulcéreuse. Le phénomène auto-immun peut prédominer dans la maladie inflammatoire de l'intestin. On note une incidence élevée de maladies auto-immunes associées à la colite ulcéreuse en particulier, y compris l'hypothyroïdie, la cholangite sclérosante primitive, le vitiligo et la pelade. L'anémie hémolytique auto-immune est bien décrite chez 0,5\% à 1,0 \% des patients adultes atteints de colite ulcéreuse, mais elle n'avait encore jamais été signalée chez les enfants atteints de cette maladie.
A utoimmune phenomena may be prominent in inflammatory bowel disease. Ulcerative colitis (UC), in particular, exhibits a high incidence of associated autoimmune diseases including hypothyroidism, primary sclerosing cholangitis (PSC), vitiligo and alopecia areata (1). Autoimmune hemolytic anemia (AIHA) is well described in $0.5 \%$ to $1.0 \%$ of adult UC patients but has not been reported in children with UC (2). A 15-month-old female who initially presented with AIHA is described. She developed bloody stools and was diagnosed with UC. Investigations of persistent hepatomegaly revealed PSC. The association of AIHA, UC and PSC has never been reported. All of these conditions entail impaired immunoregulation. Patients with a clustering of autoimmune diseases may help to delineate the pathogenesis of UC.

\section{CASE PRESENTATION}

A previously well 15-month-old female presented in October 1993 with low grade fever, coryza, lethargy, pallor and jaundice. Her liver was firm and palpable $2 \mathrm{~cm}$ below the right costal margin, and her spleen was palpable $2 \mathrm{~cm}$ below the left costal margin. Complete blood count revealed: hemoglobin $64 \mathrm{~g} / \mathrm{L}$ (normal 110 to $140 \mathrm{~g} / \mathrm{L}$ ); total white blood cell count $19.8 \times 10^{9} / \mathrm{L}$ (5 to $12 \times 10^{9} / \mathrm{L}$ ); platelets $446 \times 10^{9} / \mathrm{L}$ (150 to $\left.450 \times 10^{9} / \mathrm{L}\right)$; and reticulocytes $464 \times 10^{9} / \mathrm{L}$ (10 to $\left.100 \times 10^{9} / \mathrm{L}\right)$. Direct Coombs' test was positive. Total serum bilirubin was $94 \mu \mathrm{mol} / \mathrm{L}$ (normal less than $17 \mu \mathrm{mol} / \mathrm{L}$ ), with a direct component of $23 \mu \mathrm{mol} / \mathrm{L}$ ( 0 to $7 \mu \mathrm{mol} / \mathrm{L}$ ). Further hematological investigation revealed a positive direct antiglobulin test, with specific anti-immunoglobulin (Ig) $\mathrm{G}$ and anti-C3d.

The Hospital for Sick Children, University of Toronto, Toronto, Ontario

Correspondence: Dr SM Gilmour, Division of Gastroenterology and Nutrition, The Hospital for Sick Children, 555 University Avenue,

Toronto, Ontario M5G 1X8. Telephone 416-813-6131, fax 416-813-6531 


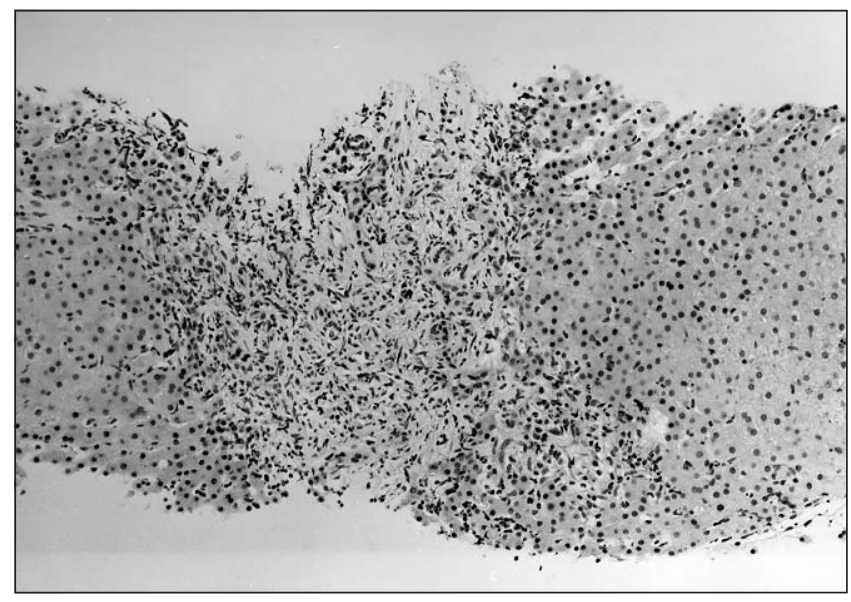

Figure 1) Percutaneous liver biopsy in a patient with ulcerative colitis and hepatomegaly of 16 months' duration. Note wide area of scarring in which there is a mild chronic inflammatory infiltrate seen. Note also extensive piecemeal necrosis. Hematoxylin and eosin stain $\times 98$

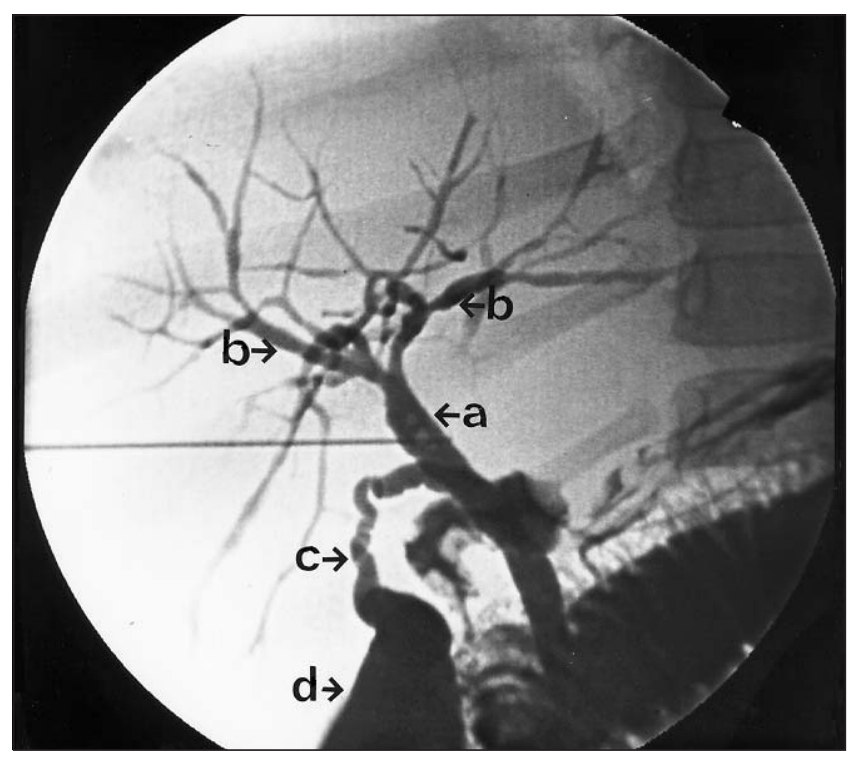

Figure 2) Percutaneous transhepatic cholangiogram demonstrating a normal extrahepatic ductal system (a) with involvement of the medium and small ducts of both left and right lobes $(\boldsymbol{b})$. Features include irregularity of the walls with areas of dilation and stenosis. Contrast fills the cystic ducts (c) and duodenum (d)

The child was diagnosed with warm-antibody AIHA and started on prednisone $2 \mathrm{mg} / \mathrm{kg} /$ day. She responded quickly to therapy; within one week hemoglobin was $91 \mathrm{~g} / \mathrm{L}$ and reticulocytes $667 \times 10^{9} / \mathrm{L}$. Physical examination revealed that both liver and spleen were smaller. By December 1993 the patient was well, with a hemoglobin level of $111 \mathrm{~g} / \mathrm{L}$. By March 1994 she had been weaned off steroids.

Although the patient was free from hemolysis she continued to have hepatomegaly. Between June and September 1994, her spleen enlarged massively until it was palpable near the left iliac crest. In November 1994, following the first episode of hemolysis since presentation, she was transfused and started on prednisone. At that time liver function tests were aspartate aminotransferase (AST) $302 \mathrm{U} / \mathrm{L}$ (normal less than $45 \mathrm{U} / \mathrm{L}$ ); alanine aminotransferase (ALT) 589 $\mathrm{U} / \mathrm{L}$ (less than $45 \mathrm{U} / \mathrm{L}$ ); and alkaline phosphatase $487 \mathrm{U} / \mathrm{L}$ (185 to $520 \mathrm{U} / \mathrm{L}$ ). One month later abdominal sonography showed mild hepatosplenomegaly with mild dilation of intrahepatic bile ducts and a widened common bile duct, but no cholelithiasis or choledocholithiasis.

In February 1995 the patient presented with a 12-day history of bright red blood mixed with stool occurring two to three times/day. There was no night-time stooling, urgency, abdominal pain, fever or vomiting. The patient's mother indicated that hematochezia had occurred intermittently during the previous 15 months. Stool cultures for bacteria, viruses and parasites were negative, as was a Meckel scan. Hepatosplenomegaly was again noted. Laboratory data revealed AST $291 \mathrm{U} / \mathrm{L}$; ALT $442 \mathrm{U} / \mathrm{L}$; ALP $438 \mathrm{U} / \mathrm{L}$; and $\gamma$-glutamyl transpeptidase $505 \mathrm{U} / \mathrm{L}$ (normal less than $45 \mathrm{U} / \mathrm{L}$ ). Total bilirubin was $49 \mu \mathrm{mol} / \mathrm{L}$ and conjugated bilirubin was less than $1 \mu \mathrm{mol} / \mathrm{L}$. Prothrombin time was normal at $11.2 \mathrm{~s}$. Further investigations revealed mildly elevated $\operatorname{IgG}(19 \mathrm{~g} / \mathrm{L}$; normal 4 to $12 \mathrm{~g} / \mathrm{L})$, and normal $\operatorname{IgA}(1 \mathrm{~g} / \mathrm{L})$ and $\operatorname{IgM}(1.7 \mathrm{~g} / \mathrm{L})$. Antinuclear factor was positive at $1 / 320$ with a homogeneous nucleolar pattern. Antismooth muscle antibody was also positive at $1 / 80$. No defects in cellular or humoral immunity were identified.

Further investigations were consistent with UC. Colonoscopy revealed a diffusely friable mucosa up to the ascending colon. Colonic biopsies showed mild to moderate inflammation with inflammatory cells within the lamina propria, and focal areas of pericryptitis. The patient was started on sulphasalazine. Percutaneous liver biopsy revealed chronic hepatitis with marked piecemeal necrosis, extensive ductular proliferation and moderate cholangitis (Figure 1). Percutaneous cholangiogram showed irregular intrahepatic ducts with 'pruning' of the ducts, thus confirming the diagnosis of PSC (Figure 2).

\section{DISCUSSION}

A unique triad of AIHA, UC and PSC is seen in our patient. The association between UC and PSC, and between UC and AIHA is well known. PSC is found in 3\% to 7\% of adult UC patients (3). Conversely, 70\% of adult PSC patients have UC (4). AIHA has been reported in $0.5 \%$ to $1.0 \%$ of adult UC patients, but there are only two cases in the literature of AIHA and PSC $(2,5,6)$. The constellation of UC, PSC and AIHA has never been reported.

PSC is not uncommon in children and may be associated with colitis $(4,7)$. Children with PSC may be more difficult to identify for several reasons. First, the association between UC and PSC is lower in children; in the largest North American series, only 55\% had inflammatory bowel disease and half of these developed it after onset of PSC (4). Second, PSC in children differs from that in adults; PSC in children frequently is limited to intrahepatic bile ducts. Thus, presentation with jaundice and increased ALP is less common than in adults. Finally, PSC in children is diagnosed on the basis of cholangiographic findings: strictures, or dilation or irregu- 
larities of the intra- or extrahepatic bile ducts. Elevated serum IgG and positive antismooth muscle and antinuclear antibodies occur commonly in children with PSC, and liver histology often has features suggestive of autoimmune hepatitis $(4,8)$. Whether PSC mimics autoimmune hepatitis or both are manifestations of a single disease process causing autoimmune hepatic disease remains uncertain.

Immunological abnormalities are important in the pathogenesis of PSC and UC. Both conditions have been associated with elevated immunoglobulins, with abnormal autoantibodies against liver cells in PSC and against colonic epithelium in UC $(9,10)$. Immunosuppressive therapy, such as prednisone and cyclosporine, is effective in UC (11). AIHA results from impaired immunoregulation. Recent in vitro work in AIHA indicates that colonic mononuclear cells may be the origin of the red cell antibodies when AIHA is associated with UC (12). Some patients have had resolution of

ACKNOWLEDGEMENTS: This paper was a winning entry in the Inflammatory Bowel Disease Resident Case Study Competition, supported by an educational grant from Astra Pharma Inc. Dr Gilmour is supported by a Duncan Gordan Fellowship of The Hospital for Sick Children Foundation and by a Janssen Pharmaceutica research scholarship.

\section{REFERENCES}

1. Snook JA, Silver HJ, Jewell DP. The association of autoimmune disorders with inflammatory bowel disease. Q J Med 1989;269:835-40.

2. Gumaste V, Greenstein AJ, Meyers R, Sachar DB. Coombs-positive autoimmune hemolytic anemia in ulcerative colitis. Dig Dis Sci 1989;34:1457-61.

3. Broome U, Glaumann H, Hellers G, et al. Liver disease in ulcerative colitis: An epidemiological and follow up study in the county of Stockholm. Gut 1994;35:84-9.

4. Wilschanski M, Chait P, Wade J, et al. Primary sclerosing cholangitis in 32 children: Clinical, laboratory and radiographic features, with survival analysis. Hepatology 1995;22:1415-22.

5. Moeller DD. Sclerosing cholangitis associated with autoimmune hemolytic anemia and hyperthyroidism. Am J Gastroenterol 1985;80:122-5. anemia with colectomy, thereby indicating that the colon may be associated with the production of anti-erythrocyte antibodies (13). Because PSC may progress after colectomy, such a similar causal relationship has not been established between colonic disease and PSC.

\section{CONCLUSIONS}

We report a child with AIHA, UC and PSC. While there have been only two previous reports of the association of AIHA and PSC, and one report of AIHA, Crohn's disease and PSC, all three conditions have the features of impaired immunoregulation $(5,6,14)$. Abnormal activation of the humoral immune system is common to all these disorders. Patients who present with unique combinations of these autoimmune conditions, as did our reported child, provide important clues to the pathogenesis of UC.

6. Scully RE, Mark EJ, McNeely WF, McNeely BU. Case records of the Massachusetts General Hospital. N Engl J Med 1991;324:180-8.

7. Debray D, Pariente D, Urvoas E, Hadchouel M, Bernard O. Sclerosing cholangitis in children. J Pediatr 1994:92:49-56.

8. El-Shabrawi M, Wilkonson ML, Portmann B, et al. Primary sclerosing cholangitis in childhood. Gastroenterology 1987;92:1226-35.

9. Jackson WD, Grand RJ. Ulcerative colitis. In: Walker WA, Durie PR, Hamilton JR, Walker-Smith JA, Watkins JB, eds. Pediatric Gastrointestinal Disease. Toronto: BC Decker, 1991:609-10.

10. Mieli-Vergani G, Lobo-Yeo A, McFarlane BM, et al. Different immune mechanisms leading to autoimmunity in primary sclerosing cholangitis and autoimmune chronic active hepatitis of childhood. Hepatology 1989;9:198-203.

11. Lichtiger S, Present DH, Kornbluth A, et al. Cyclosporine in severe ulcerative colitis refractory to steroid therapy. N Engl J Med 1994;330:1841-5.

12. Yates P, Macht LM, Williams NA, Elson CJ. Red cell autoantibody production by colonic mononuclear cells from a patient with ulcerative colitis and autoimmune hemolytic anemia. $\mathrm{Br} J$ Haematol 1992;82:753-6.

13. Clements D, Carter C, Allan R. Autoimmune hemolytic anemia complicating ulcerative colitis. Br J Hosp Med 1988;40:70.

14. Eilam O, Goldin R, Shouval D, Gimon T, Brautbar C. Sclerosing cholangitis associated with Crohn's disease and autoimmune haemolytic anaemia. Postgrad Med J 1993;69:656-8. 


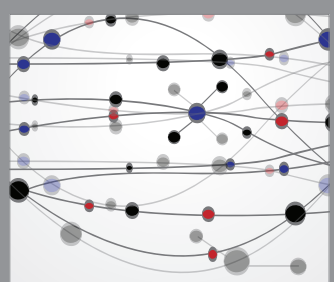

The Scientific World Journal
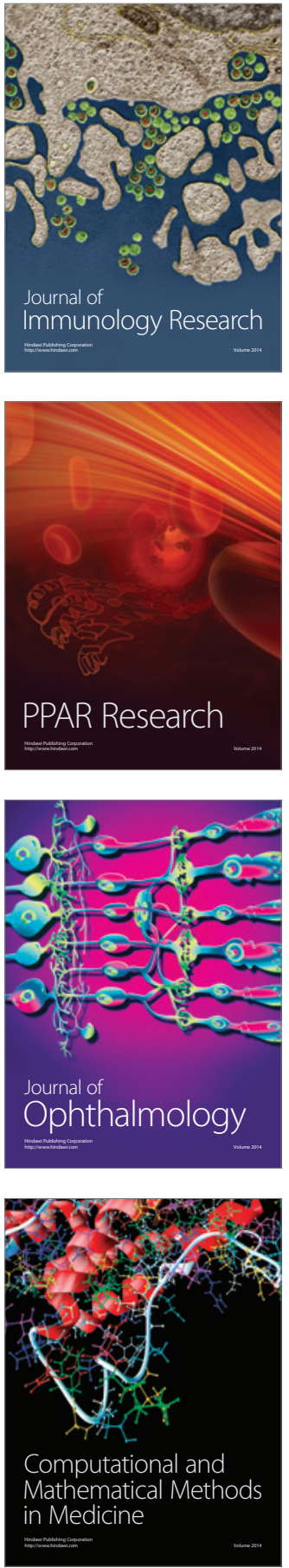

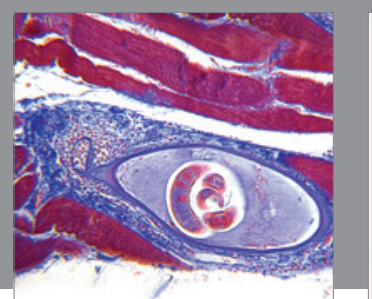

Gastroenterology Research and Practice

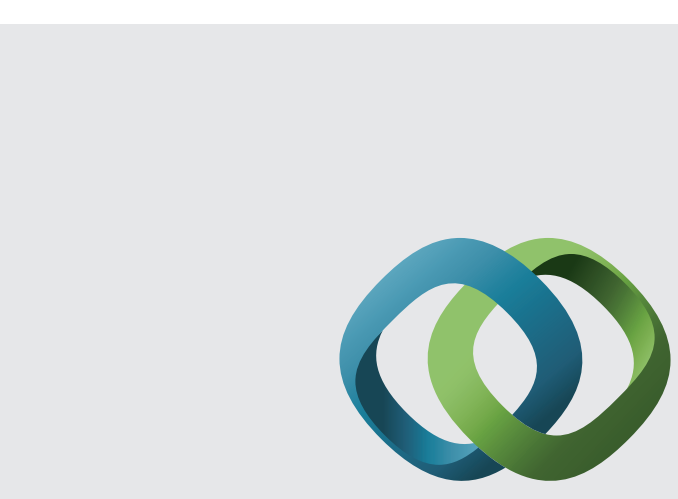

\section{Hindawi}

Submit your manuscripts at

http://www.hindawi.com
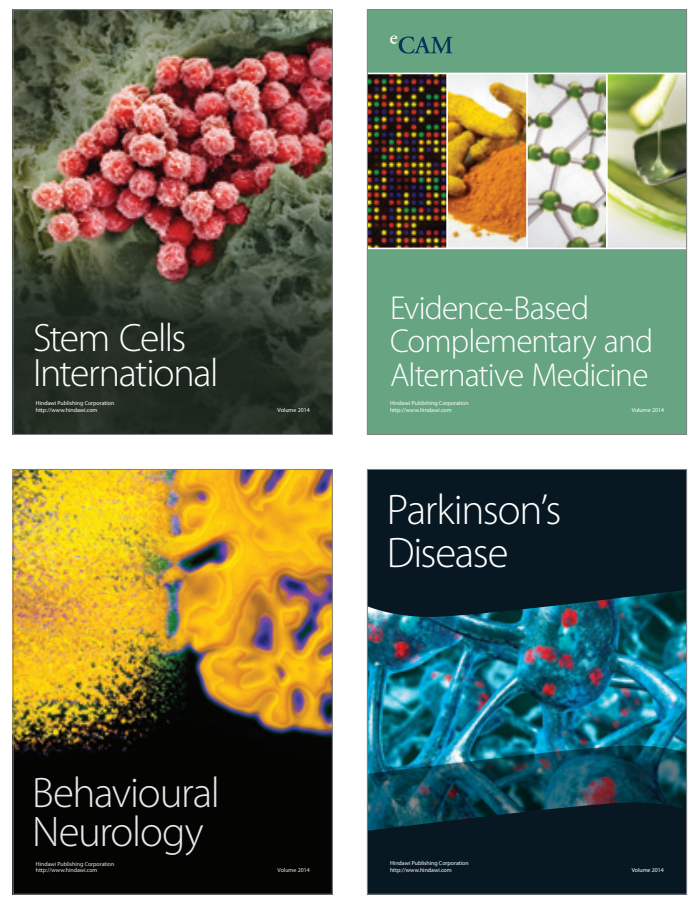
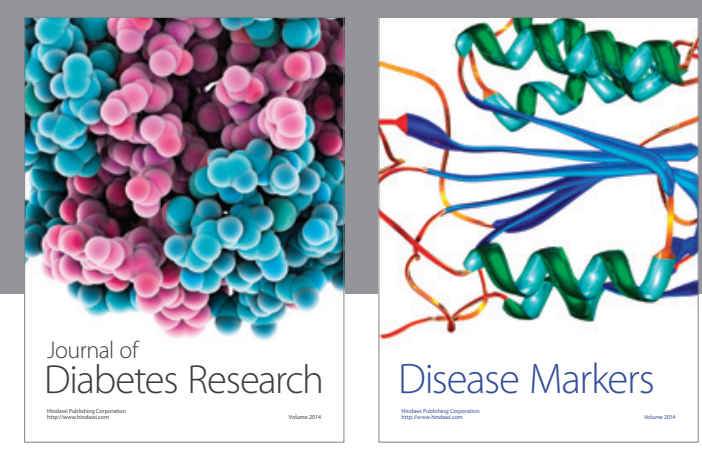

Disease Markers
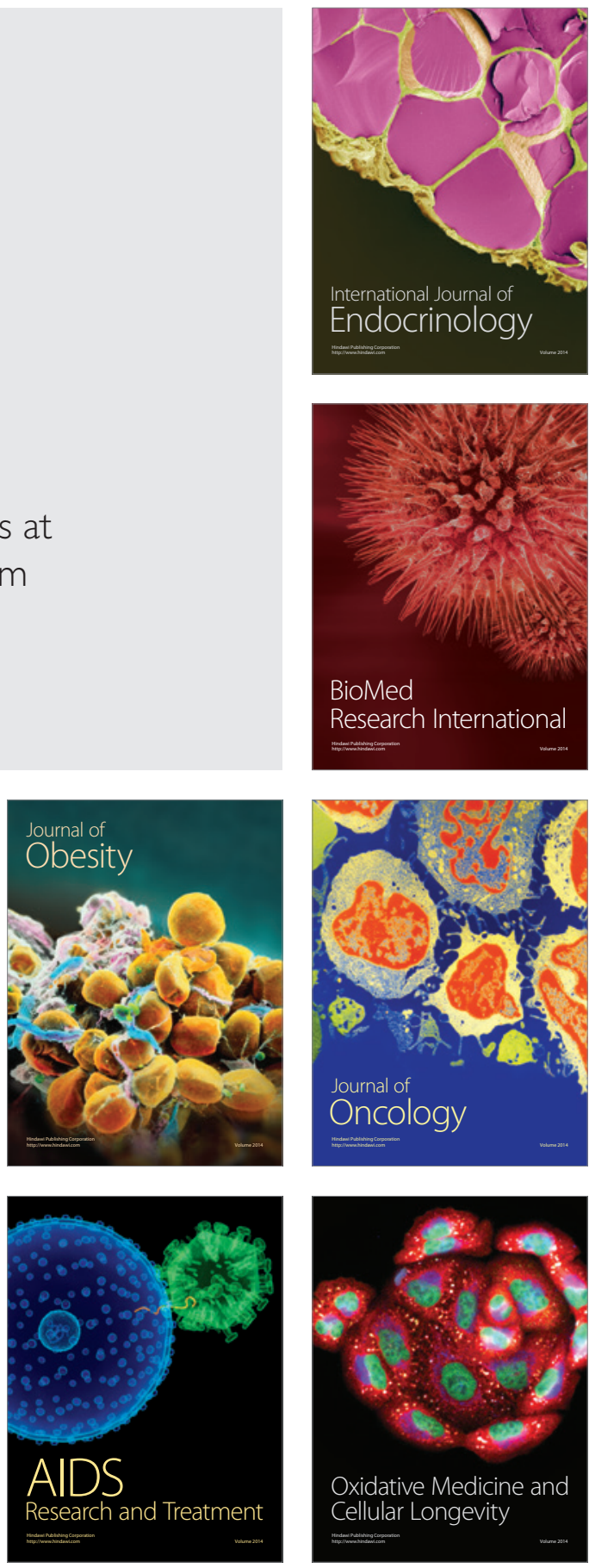